This item was submitted to Loughborough's Research Repository by the author.

Items in Figshare are protected by copyright, with all rights reserved, unless otherwise indicated.

\title{
Reforming a university during political transformation: a case study of Yangon University in Myanmar
}

\section{PLEASE CITE THE PUBLISHED VERSION}

http://dx.doi.org/10.1080/03075079.2016.1239250

\section{PUBLISHER}

(c) Society for Research into Higher Education. Published by Taylor \& Francis

\section{VERSION}

AM (Accepted Manuscript)

\section{PUBLISHER STATEMENT}

This work is made available according to the conditions of the Creative Commons Attribution-NonCommercialNoDerivatives 4.0 International (CC BY-NC-ND 4.0) licence. Full details of this licence are available at: https://creativecommons.org/licenses/by-nc-nd/4.0/

\section{LICENCE}

CC BY-NC-ND 4.0

\section{REPOSITORY RECORD}

Esson, James, and K. Wang. 2019. "Reforming a University During Political Transformation: A Case Study of Yangon University in Myanmar". figshare. https://hdl.handle.net/2134/22555. 
Esson, J and Wang, K (2016) Reforming a university during political

transformation: A case study of Yangon University in Myanmar. Studies in Higher

Education

Version: Accepted for publication

Please cite the published version. 


\title{
Reforming a university during political transformation: A case study of Yangon University in Myanmar
}

\begin{abstract}
Since 2010, Myanmar has been transitioning from an authoritarian military regime towards a parliamentary democracy. Several education policies have been launched as part of this political transformation process, including the reform of Myanmar's flagship higher education institution, Yangon University. This article investigates the reform of Yangon University. Through so doing, we examine a key node in Myanmar's higher education system, and contribute to academic debates over higher education reforms in countries undergoing political transformations. The article draws on qualitative data obtained from stakeholders involved in the reform of Yangon University, and uses Arnhold et al.'s 'educational reconstruction framework' to conceptualize the reform process. It is argued that while improvements have been made to the physical infrastructure, there has been a failure to consider the ideological and psychological reconstruction of the university, which staff and students alike deem essential to transforming long standing authoritarian practices, and creating a constructive learning environment.
\end{abstract}

Keywords: Myanmar (Burma); Yangon University (Rangoon University); Educational Reconstruction; Qualitative Research; Educational Policy 


\section{Introduction}

We have chosen to start our reforms of the education system with Rangoon University (Aung San Suu Kyi cited in Weng, 2012)

Myanmar (commonly known as Burma) has been described as a 'hermit nation' (Holsti 2015), due to the country being ruled from 1962 to 2010 by a secretive and authoritarian military regime, which discouraged relations with the outside world. Significantly, for the subject of this paper, several decades of authoritarian rule resulted in a dearth of research on Myanmar's higher education system. Since 2010, attempts have been made to move from authoritarian rule and towards a parliamentary democracy, as evidenced by the adoption of a new constitution and subsequent nationwide elections held in 2010 (Aung-Thwin \& Aung-Thwin 2013). Internal and external observers criticized the elections for a lack of transparency. Nonetheless, the elections did lead to the formation of the Assembly of the Republic of the Union of Myanmar (Myanmar Parliament), which paved the way for the 2015 parliamentary elections won by Aung San Suu Kyi's 'National League for Democracy' in the November 2015 elections.

In November 2012, a special parliamentary committee was formed to oversee the reform of Yangon University (formerly known as Rangoon University). The 'Yangon University Renovation and Upgrading Committee' is chaired by Aung San Suu Kyi, and comprises; five Parliamentarians, five retired senior academics, two senior officials from the Ministry of Education (two current Director-Generals), the Rector of Yangon 
University, head of Department of International Relations (Yangon University), and head of Department of Industrial Chemistry (Yangon University). Following the creation of the special parliamentary commission in 2012, Yangon University was designated as a 'Centre of Excellence', and given priority to upgrade its facilities to international standards.

The reform of Yangon University will be used as the template for country wide university reforms, and has therefore attracted a great deal of interest both domestically and internationally (Institute of International Education 2013; McKenzie 2013; Weng 2012). A notable example of this international interest is the historic speech by Barack Obama, the President of the United States of America, at the University's Convocation Hall on November 19th 2012. During the speech, President Obama highlighted the government of Myanmar's pledge to 'revitalize' Yangon University, and he also stressed the important role that education will play in Myanmar's ambitions to enact democratic governance (Obama 2012). However, despite considerable public and political interest in the reform of Yangon University, the above-mentioned challenges associated with conducting research on higher education remain, and there is a lack of empirical research on the reform process itself.

This article aims to address the lack of research on Myanmar's higher education system by investigating the reform of Yangon University. As highlighted in the above-quote from Aung San Suu Kyi, who at the time of writing is expected to have an executive role in the post 2015 government, Yangon University figures prominently in the country's Comprehensive Education Sector Reform (CESR) agenda (see Asian 
Development Bank 2012; Myanmar Ministry of Education 2012). Accordingly, this paper focuses on addressing the following research question; 'what are the main challenges facing the current reform of Yangon University?' To answer this question, we adopt an exploratory approach that is based on a qualitative methodology. This allows us to bring the subjectivities of key stakeholders to the fore, and pinpoint key challenges from a variety or perspectives.

This article consists of six sections inclusive of this introduction. The next provides a brief review of literature about educational reform in developing countries, and an overview of the conceptual framework used in this paper. We then outline the study's methodological approach and the data collection process, after which we present the key findings. This is followed by a summary of the key findings and their implications for research on higher education reforms by developing countries in the Global South undergoing political transformations.

\subsection{Conceptual framework and literature review}

This study uses the Arnhold et al. 'educational reconstruction' conceptual framework, which addresses educational reconstruction 'in countries that have experienced crisis of various kinds' $(1998,11)$, to examine the higher education reform process taking place in Myanmar. Crisis is defined in the framework to include various kinds of war and conflict, natural disasters and countries in transition after extreme political and economic upheaval and rapid political change. This framework is therefore fitting for the purposes of this study, as Myanmar has recently undergone a shift from military 
dictatorship towards parliamentary democracy. Moreover, there are also a variety of on-going ethnic and religious conflicts taking place across the country (Holliday, 2010).

Arnhold et al. $(1998,11)$ identify five processes of educational reconstruction:

1. Physical reconstruction

2. Ideological reconstruction

3. Psychological reconstruction

4. Provision of materials and curricular reconstruction

5. Human resources development

When seeking to reform a university after any major crisis, as defined above, the reconstruction of institutional physical infrastructure such as buildings, classrooms, facilities, supply of electricity and water to re-engage or improve educational provisions often takes precedence. However, it is also necessary to reform authoritarian systems and individual attitudes through ideological reconstruction of the institution, to engender a democratization of education by exposing academics and students to democratic rights, values and procedures, as well as critical and creative skills.

Psychological reconstruction is necessary to help staff and students address symptoms associated with the transformation process, such as; frustration, low morale, anxiety, depression, stress and nostalgia. All of which can result from the uncertainty, insecurity and instability they may face as part of the transition to a new working and learning environment. Another important process in educational reconstruction is to provide necessary educational materials and equipment. This should take place 
alongside an evaluation of teaching and learning methods to ensure the incorporation of democratic values, and to encourage critical thinking and learning within the curriculum.

Human resources development is necessary to address immediate concerns as well as for long-term institutional development. Various human resources development programmes should be conducted including capacity building of management and academics through various international collaboration programmes and local training programs. These programs should ultimately lead to more efficient management structures with a progressive management culture, and the establishment of centres of excellence to promote research. Human resources development also needs to address the changing educational needs accompanying political and economic changes.

\subsection{Literature Review}

In the brief literature review that follows, we use the 'educational reconstruction' framework to reflect on various issues commonly associated with university reforms. We focus on the following themes within literature on university and higher education reforms in developing countries and/or facing crisis, namely; participation of key stakeholders; funding; capacity building of university administrators, academics and students; university governance; and academic freedom. These themes will help inform our later analysis of key challenges facing the reform of Yangon University in Section 4.

University reform, like other processes leading to significant institutional change, involves a relinquishment of the status quo in the hope of obtaining something 
better in the future. This situation is argued to create an uncertain and insecure atmosphere for academics and staff, especially in the early stages of reform (Arnhold et al. 1998). A key way to alleviate this sense of an uncertain and insecure atmosphere is to ensure that the identification and participation of key stakeholders is a central element of the university reform process (Marga

1997). The involvement of key stakeholders - including student representatives - in the master planning process for university reform helps to establish shared goals and their active involvement at various stages of the reform (Musisi \& Muwanga 2003).

The involvement of key stakeholders entails establishing opportunities for dialogue among and between individuals involved in the reform, as well as providing adequate support to those responsible for the implementation of policy at the institution level (Arnhold et al., 1998). For example, Luhanga (2010) highlights how in the case of the University of Dar-es-Salaam in Tanzania, it was necessary to mobilize support for the reform process by involving staff, students and the media. Although concerns remained with certain decisions, this approach helped provide greater transparency and a more collaborative ethos, thereby alleviating resistance to change in the early stages of reform caused by perceptions of top-down decision-making (Luhanga, 2010).

Funding is an issue that affects university reform in developed and developing countries alike (Esson \& Ertl 2013; Luhanga 2010). However, a lack of financial resources is often an acute source of concern for universities located in developing countries. University reforms in developing countries, particularly following years of 
deterioration, require massive upgrading (Luhanga 2010; Musisi \& Muwanga, 2003). For example, after the nation gained independence in 1992, UNESCO estimated that the reconstruction of the University of Sarajevo in Bosnia required US\$ 56 million of funds (quoted in Arnhold et al., 1998, 41). Likewise, university reforms in Asian and African developing countries invariably require significant upgrading of educational facilities, such as libraries, laboratories, the Internet, and teaching and learning materials. In the case of Myanmar, a recent report by the Institute of International Education highlights the magnitude of educational reconstruction required to upgrade facilities adequately, and states that 'the entire system requires nothing less than a complete renovation - from the physical infrastructure to the academic curriculum' $(2013,17)$.

Funding from the State to upgrade educational facilities is often insufficient. Institutions located in developing countries therefore often generate additional income from student fees and external sources, such as international donors, nongovernmental and industry partners (Amonoo-Neizer 1998; Batsukh 2011; Johnstone et al., 1998; Marga 1997). Problematically, these and other strategies fail to address one common financial issue facing many university reforms in many developing countries, which is the low salary paid to academic staff. The paucity of financial remuneration contributes to the issue of 'brain drain', with capable academics emigrating in search of better opportunities on the international job market (Amsterdamski \& Rhodes 1993; Cerych 1995; King 2009, 2013; Luhanga 2010; Musisi \& Muwanga 2003; Teferra \& Altbach 2004). 
Capacity building is one of the most important challenges when reforming universities in post-dictatorship developing countries. University reconstruction in these countries is complex and multifaceted (Luhanga 2010). It involves improving quality and relevance of degree curricula and educational materials, teaching methods, as well as enhancing research capacity. It is therefore necessary to take into account ideological reconstruction and psychological reconstruction also (Arnhold et al., 1998). For example, although significant autonomy may be given to universities as part of the reform process, legacies of authoritarian rule may prohibit the use of pedagogical approaches and curricula that encourage the questioning of the State (Deaver 2001). Thus where possible, the capacity building of academics and students should involve exposure to and engagement with democratic ideas, rights and procedures. This approach will provide a way to change the attitudes of academics and students, and undermine authoritarian structures and culture (Arnhold et al., 1998).

Institutional autonomy and academic freedom connect with two aspects of university governance - university autonomy and leadership - that appear as central themes in research on university reforms in post-authoritarian developing countries. Anderson and Johnson define university autonomy as 'the freedom of an institution to run its own affairs without direction or influence from any level of government' (1998, 8). On the one hand, university autonomy provides new opportunities for academics and university administrators, such as international collaboration, which is an important factor when attempting to instill new pedagogical approaches and research ethos (Amsterdamski \& Rhodes 1993), and facilitate capacity building (Cerych 1995). On 
the other hand, university autonomy also creates new challenges for university administrators, such as independent decision-making and generating new ways to obtain non-governmental funding. These funding challenges are particularly difficult for countries with a weak economy and no tradition of non-governmental financing (Hendrichov 1995). Consequently, public universities can often find themselves competing among themselves for 'scarce public and private resources' required for their reconstruction and development, and in emerging market economies they may be competing with the private higher education providers also (Sadlak 1995, 217).

Anderson and Johnson $(1998,8)$ note that 'institutional autonomy is a necessary but not a sufficient condition for academic freedom' (see also Karran 2009; Hall \& Symes 2005). Academic freedom can be and frequently is misinterpreted as the 'unchallenged right' of individual academic staff 'to determine content of their courses' (Rosovsky \& Ameer 1998 cited in Dill 2000, 221). Yet, at its simplest, academic freedom involves notions of freedom for academic staff to teach and research 'without external control', 'freedom for students to learn' (Altbach 2007, 50), and the space to communicate research findings and ideas 'without any fear of persecution' (Teferra \& Altbach 2004,40$)$. Academic freedom therefore enables scholars to search for new ideas, to challenge the status quo, and to test widely accepted views (Teferra \& Altbach 2004). Accordingly, governments in countries undergoing the transition to democracy are encouraged to put in place measures to facilitate institutional autonomy of universities and academic freedom in the early stages of their higher education reform process (Batsukh 2011; Sadlak 1995b). 
At a managerial level, the university reform process requires strong and committed leadership (Luhanga 2010), as well as enhanced management capabilities in decentralized departments (Farrant \& Afonso 1997). Musisi \& Muwanga $(2003,31)$ note that a combination of approachable and accountable university administrative staff alongside the 'subtle but effective' leadership of the Vice-Chancellor was a significant factor in bringing fundamental changes to Makerere University. Leadership at departmental level is also important as reform-oriented leaders can shape the attitudes of the staff and implement new approaches to learning and teaching (Bennich-Björkman 1999; Deaver 2001). Effective internal communication and collaboration between central university administration, faculties and departments is therefore crucial to the university reform process (Higgs 1998).

\subsection{Methodology and data collection}

Yangon University was chosen as a case study for this research because as stated above, the government of Myanmar identified the University as being central to the reform of the higher education system, and it is likely that the university will be used as a template for wider reforms. Due to the shortage of empirical research on this topic, we adopted an exploratory approach based on a qualitative methodology. We acknowledge that this approach has implications for the generalizability of our findings, however, it encourages the investigation 'of meanings which people use to make sense of their world and their behaviour within it' (Cohen et al. 2011, 9), which in turn 
allowed us to try and understand the experiences, perceptions and expectations of stakeholders involved with the reform process.

This research sought to investigate a social institution (university), social processes (reform activities) and social actors (various key stakeholders), as well as how the social phenomena (challenges) are constructed and interpreted by social actors embroiled in the process itself. To achieve this objective, in-depth semi-structured interviews were conducted with corresponding qualitative analysis in the form of transcription and translation. Thematic in-vivo coding followed this. Importantly, in an authoritarian environment not known for permitting freedom of speech, face to face interviewing allowed us to pick up 'non-verbal cues' and get a better understanding of the contexts and concerns of interviewee's 'verbal responses' (Robson, 2002: 273).

Fieldwork took place in Yangon over a four-week period in mid-2013. Ethical clearance was obtained from the University of Oxford's Central University Research Ethics Committee. Upon arrival in Myanmar, we visited the Department of Higher Education, which is an executive branch of the Ministry of Education, and we submitted an information sheet outlining the purpose of the research and a sample interview guide. In addition to these documents, we provided a verbal explanation for undertaking the research. We were subsequently denied access to certain higher education policy documents, but received a recent Myanmar higher education review booklet. In addition to our meetings at the Ministry of Education, we also met the Rector of Yangon University. The Rector provided permission to; tour the University's main campus and observe physical aspects of the reform, conduct interviews with staff 
and students on campus, and consult documents at the Universities' Central Library (UCL).

Yangon University has twelve Science departments and eight Arts departments teaching various degrees within the Arts, Social Sciences, and Humanities. A purposive sampling strategy was adopted to try and ensure that university staff and students from both the Sciences and Arts were included in the study; it is however appropriate to note that some staff and students were reluctant to take part. In short, we were informed that several decades of authoritarian military rule has made people extremely cautious when discussing matters involving Myanmar's government. Given that the government is leading the reform process, staff and students deemed it a politically sensitive topic, and were thus apprehensive about the implications of their involvement in the research project. Twenty-two people participated in the research despite these concerns, but as discussed below, this was based on the proviso that we would ensure anonymity. Fifteen out of the twenty-two participants were female, a situation that reflects the significantly higher proportion of female academics and students at the University. The ratio of male to female academics for the 2012-13 academic year was 1:6, while the ratio of male to female students was 1:3 (Yangon University, 2013).

The makeup of participants was as follows; four heads of department from the Arts and four heads of department from the Sciences, two professors located in the Arts, one lecturer located in the Sciences, two senior university administrators, one library officer, one PhD student in the Arts, one PhD student in the Sciences, one 
Master's student in the Arts, one Master's student in the Sciences, two retired heads of departments from the Arts, one retired head of department from the Sciences and one parliamentarian (policy maker). The interviews with university staff were stopped once data saturation point occurred, however, a case could be made that further research incorporating insights from a wider pool of staff would be beneficial, as divergent views may exist. Moreover, the number of interviews with students was limited by this population group's reluctance to take part in the study for the reasons mentioned above. We therefore acknowledge that while our subsequent data analysis identified common themes, the students who were willing to take part in the research could have characteristics that set them apart from their peers who did not want to be interviewed. This in turn means that the views obtained may not be representative of the wider student body.

Senior Ministry of Education officials are steering the Yangon University reform process, and the University Rector is in charge of implementation. Unfortunately, we could not get their perspectives on the reform as requests to interview Ministry officials and the Rector were rejected. The perspectives provided in this paper could therefore be viewed as consisting primarily of stakeholders with limited executive power. However, we contend that while these stakeholders may have limited executive power, their day-to-day activities leave them well placed to provide insights on the reform process. Moreover, four of the interviewees are also members of the special parliamentary committee for the renovation and upgrading of Yangon University. 
All of the interviews were conducted in Myanmar (Burmese) language and we requested permission from participants to audio-record interviews. However, due to fears of reprisal, several participants stated that they felt uncomfortable sharing their thoughts and opinions if the interview was recorded. Although it significantly prolonged the duration of the interview, we always respected the preference of interviewees not to be audio-recorded, and took detailed notes of the conversation instead. Pseudonyms were used at every stage of the research process in order to preserve the anonymity and confidentiality of participants, and audio-recorded interviews were stored on a password-protected electronic device. Notwithstanding these measures, some interviewees still felt they could not fully discuss issues of autonomy and academic freedom due to the politically sensitive nature of these topics.

\subsection{Reforming a university in post-socialist Myanmar: A case study of Yangon University}

In this section, we frame our analysis around the 'educational reconstruction framework' introduced in Section 2, and the associated five reconstruction processes, namely, physical reconstruction, provision of materials and curricular development, ideological reconstruction, psychological reconstruction, and human resources development (Arnhold et al., 1998). In order to protect the identity of participants and to ensure their safety we have deliberately avoided attaching personal identifiers to quotations. 


\subsection{Physical reconstruction and the provision of materials}

Since late 2012, the Myanmar Ministry of Education has provided increased funding for the physical renovation and upgrading of Yangon University as part of the reform process. According to a senior university administrator, the budget provided by the Ministry of Education for 2012 to 2013 of Kyats $6,446.6$ million (approximately $\$ 7.2$ million) was more than double the previous year's budget. The additional funds, which were provided for the renovation and upgrading of the university, were only made available towards the end of 2012. According to several participants, this conveniently coincided with the visit of President Barack Obama in November. In addition to the funds provided by the Ministry of Education, there was also a donation of Kyats 500 million (approximately $\$ 555,000$ ) made by Yangon University alumni. So how was the first allocation of funds from the Myanmar Ministry of Education used?

Thus far, the physical renovation of Yangon University includes the painting and decorating of public areas, academic buildings, classrooms, and a couple of student halls of residence. A recurrent theme within the interviews was that these initial efforts should have been directed at upgrading basic university facilities such as water and electricity supplies, rather than cosmetic upgrading. Furthermore, although the renovated buildings and classrooms are in working condition, they are not at a satisfactory standard, with broken lights, dilapidated flooring and poor ventilation the norm. This situation was a factor in recent high profile student demonstrations (Mann, 2014); with interviewees complaining that areas like the canteen, public rest rooms, 
and the vast majority of academic and student halls of residence remain untouched. The head of an arts focused academic department described the situation as follows;

The student halls and houses for academic staff have not been part of the renovation plan yet. Some of the halls and houses are in really bad condition and a few academic staff just repairs them out of their own budget.

The inadequacy of educational facilities, the required transformation of teaching and learning methods, and curricular reconstruction are common themes raised by studies on Myanmar's higher education system (see Asian Development Bank 2012; the Institute of International Education 2013; McKenzie 2013). Notably, all of the interviewees were able to provide examples of how the reform process has led to the provision of materials such as upgraded laboratories and technical equipment. Various departments have also received extra funding as part of the reform process, with one senior university administrator describing how their research centre received USD $\$ 100,000$ in the 2012-2013 budget year, compared to USD $\$ 1,000$ per annum previously, as well as additional funding for renovation.

Interviewees were undoubtedly pleased with the injection of funds and provision of materials that has taken place as part of the reform process, but that appreciation could not mask an awareness that what has been provided is still insufficient in terms of the quantity and quality needed for the University to function at 
internationally acceptable academic standards. A library officer highlighted that both of the main libraries still do not have a computerized search facility, and people still have to use manual card-catalogues for book searches. This leads to frustration, as on the one hand, the prospect of better educational materials is no longer a pipe dream. On the other, there is a sense that now they have glimpsed what could be, international standards will not become reality unless resources are distributed more astutely.

\subsection{Ideological and psychological reconstruction and human resource development}

Our findings indicate that ideological reconstruction is a significant challenge facing the reform of Yangon University. Most of the staff at the University, like their generation as a whole, were educated and have worked under successive dictatorships their entire lives, with limited or no international exposure. Academic staff explained how the shift from a military regime to democratic forms of governance has not led to a change in day-to-day working practices. Heads of department explained how they and other members of staff are unable to perform basic administrative duties without approval from the Rector. Moreover, the head of department has to prepare and submit a report listing departmental assets, staff details and student attendance to the Rector every month. The Rector then compiles the departmental reports and sends a comprehensive document to the Ministry of Education.

These efforts to maintain a sense of domestic control notwithstanding, academic staff explained that after many years of isolation, they are now 'allowed' to engage in international collaboration with other institutions. Key to this change is a 
sense among staff that the government is no longer in denial about the University's standing in relation to other institutions internationally;

The main positive change since the reform is that all people of Myanmar, including the government, acknowledge that the quality of university education of Myanmar is quite low in the international context. Previously, the government and officials denied this fact and kept saying the standard was high.

The rationale for permitting international collaborations is to facilitate the capacity building of academics and students. Several notable collaborative projects have been launched at Yangon University, such as; visiting academics programmes with the Open Society Foundation, two centres of excellence - one in collaboration with the University of Cologne (Germany), and the other a joint venture with Johns Hopkins University (USA) and Chung Aung University (South Korea), and the e-Tekkatho project (an on-line and off-line library database project) with the University of Manchester (UK). Staff and students both emphasized a hope that these international collaborations and other future international exposure will serve as catalysts for the long process of ideological reconstruction ahead.

It must be noted that all collaborative activities require prior approval from the Ministry of Education, and all collaborations that are approved are overseen and monitored by the Ministry. Moreover, there are restrictions on signing memorandums 
with international institutions. Academics also need permission from the Ministry of Education to attend overseas conferences and workshops, or to apply for overseas scholarships. A third year PhD student described the situation as follows;

The Ministry has already released an order that academic staff are allowed to source and apply for overseas scholarships independently, and will be given permission to go if successful with those applications... However in reality we are not allowed to go. One colleague from [Redacted] applied and got sponsorship for a workshop in an ASEAN country, but the Ministry did not give permission to join the workshop.

Alongside having their international mobility curtailed, the issues of low salaries, staff shortages and long working hours were having a significant impact on staff morale also. As noted above, poor remuneration is a common issue within higher education settings in many developing countries. Nonetheless, the fact that salaries had not yet been discussed as part of the reform process was a particularly noticeable source of frustration among academic staff. The current monthly salary for a professor is approximately Kyats 230,000 (approximately \$256), and a lecturer is approximately Kyats 170,000 (approximately \$189). A key obstacle to addressing this issue is that academic staff are classed as government employees, and salary scales for all government employees are set by the central government. Thus, wages are inextricably tied to the whims of politicians, which leave academic staff feeling powerless to remedy 
their situation. Additionally, the majority of academics have to undertake both academic and administrative duties, and it is now common for staff to work seven days a week. This conflation of academic and administrative duties leaves staff feeling physically and psychologically fatigued. Yet, like the issue of salaries, the head of an arts focused department noted that the problem of staffing levels has thus far been excluded in reform discussions.

Despite these challenges, there are some positive psychological outcomes from the on-going reform activities. All of the academic staff and some university administrators interviewed placed a noticeable emphasis on capacity building and human resources development as part of the reform of Yangon University. Notably, the academic staff argued that human resources development and capacity building should be foregrounded within the reform process as soon as possible, because this is crucial to generating more critically informed pedagogies and curriculum development. Participants stressed that this would not only lead to better quality and academically relevant research outputs, but more importantly, it will enhance the level of education provided to students and lead to a more critically informed citizenry.

\subsection{Reflections}

The findings above indicate that the reform process explicitly aims to upgrade the University's "hardware" (infrastructure and facilities) and its "software" (academic quality). Accordingly, higher priority has so far been given to the physical reconstruction process, provision of materials, and human resources development 
process. Problematically, although ideological reconstruction and psychological reconstruction are a necessary and essential part of an effective and sustainable University reform process, these reconstruction processes suffer from underinvestment currently. In the section that follows, we place interpretive weight on a key challenge that cut across all five of the reconstruction processes, specifically, centralized bureaucracy and authoritarian control.

\subsection{Painting over old attitudes? The legacies of authoritarian control}

We began the previous section by highlighting how the current physical reconstruction process has been heavily criticized for not consulting professionals such as architects and environmental engineers to help draw up a more coordinated plan. These were not the only people missing from the discussion, academic staff, including heads of departments, expressed concern that decisions were being made with little or no input from faculty. For example, a special parliamentary committee was set up for the renovation and upgrading of Yangon University in November 2012. Yet in reality, the Ministry of Education is steering the current physical reconstruction of the University, which has created a situation whereby details of the physical reconstruction plan for the University are unknown or unclear to the heads of departments interviewed for this study. This brief example is illustrative of a key issue that emerged from the interviews, and cut across the five reconstruction processes, namely, concerns over the pervasiveness of centralized bureaucracy, which has become emblematic of governance at the University following several decades of authoritarian rule. 
The continual authoritarian style of leadership exacerbates preexisting problems, and fosters feelings of uncertainty and insecurity among staff and students. For example, interviewees complained that policies associated with the current university reform are often implemented with little or no consultation with academic and/or administrative staff. Thus many actors at various levels do not have a clear idea of their role, responsibilities, what they are aiming to accomplish, and where they are heading as part of the university reform. This fosters a climate of perpetual uncertainty, and a pronounced level of psychological strain among University staff who feel disconnected from the decision making process. As noted by Musisi \& Muwanga (2003) and Luhanga (2010), ensuring the involvement of key stakeholders, including academic staff and students, is essential during the master planning process for university reform to help identify areas in need of improvement, establish shared goals, and promote transparency. This broader stakeholder involvement is not possible currently because Yangon University is still operating within a highly centralized system (under the complete control of the Ministry of Education), where the previous authoritarian structures and bureaucratic administrative procedures remain in place.

In this context, permission from the Ministry of Education is needed when attempting to incorporate fieldtrips as part of the university curriculum. At present, a proposal must be submitted to the Ministry of Education sixty days in advance for any field trip, an increase on the forty-five day requirement. The head of an arts focused department noted how it is both inconvenient and practically impossible to wait sixty days to get permission for certain fieldwork activities, because they could be 
dependent on climatic conditions or a need to make use of opportunities immediately as and when they arise.

The challenges faced by academics and students attempting to take part in collaborative initiatives, and undertake fieldwork as part of their curriculum, are inextricably tied to long standing and ingrained attempts to control academic freedom. Notably, academics and students in the 'hard sciences' said they were generally free to conduct research as they wish. Yet the remaining interviewees in the arts and social sciences noted having limited or no academic freedom to conduct research on their own terms. One head of department based in the arts, explained that all research proposals have to be submitted to the Ministry of Education not only for funding, but general approval, and the Ministry does not approve research topics deemed 'politically sensitive'. Another head of an Arts focused department explained how research findings were often 'undermined'. If Ministry officials did not accept the research findings, they would ask for data or the report itself to be changed. If researchers refuse to make the changes demanded, the project is abandoned.

$\mathrm{PhD}$ students are also impacted by challenges associated with a lack of academic freedom. For instance, a second year PhD student at an Arts department mentioned that it is extremely difficult to obtain data from government ministries as they are reluctant to provide information. Students therefore try to find research topics that do not involve dealing with the ministries, and often have to change research topics because they cannot get the necessary data. Frustratingly for some, university regulations do not allow changes to $\mathrm{PhD}$ thesis titles after the second year, which 
creates significant problems for students who are unsure if they will be able to access key data sets.

The examples above clearly illustrate why interviewees were keen to emphasize that while physical reconstruction is taking place, albeit in a superficial and haphazard manner, and material resources are being made available, there is a fundamental lack of democratic processes, participation, and representation of academics and students in the planning of the University reform. Participants attributed this to the University's lack of institutional autonomy, and pointed out that academic staff lack freedom in almost all aspects of their work, including; student admissions, research, fieldwork, organizing seminars, and international collaboration. In light of these conditions, they argued that it was therefore unlikely that academic staff and students would be granted opportunities to participate in debates over the reform of the University.

In order to gain more influence and involvement in the reform process, the majority of interviewees suggested that a necessary step in the capacity building of Yangon University's senior administrators and academic staff is consistent and sustained interaction with the international community. This is because engagement with the international community should, in theory, provide exposure to democratic ideas, rights and procedures. Moreover, we would add that due to decades of isolation, engagement with the international community could help staff to develop an appreciation that freedom in the academic world is not solely about being able to make the decisions once made by ministry officials and rectors. These changes would in turn 
provide a way to alter the attitudes of key stakeholders, who could then dismantle the authoritarian and bureaucratic structures and culture permeating the University. Yet several of the more senior interviewees made an important observation on this issue, they noted that it is problematic to focus solely on giving autonomy to, and promoting academic freedom in, Yangon University. This approach would neglect the remaining 162 public higher education institutions currently existing under the control of thirteen ministries.

What is actually needed are substantial structural changes to the ideological ethos underpinning Myanmar's Higher Education system as a whole, which cannot be achieved if efforts to engender a culture of institutional autonomy and academic freedom is limited to a handful of individuals in one or two universities. The likelihood of this structural change happening during the previous military regime was remote. However, given that the adoption of democratic procedures is directly linked to, and influenced by, the political transformation taking place in the society and the country in which the University operates, the recent success of the 'National League for Democracy' in the November 2015 elections provides cause for optimism.

\subsection{Conclusions}

In March 2011, the newly formed Myanmar government embarked on a process of political transformation. The government launched several major educational reform initiatives as part of this process, including the reform of Yangon University. This article investigated the reform of Yangon University using qualitative data obtained from 
stakeholders involved in the Yangon University reform process, and Arnhold et al. (1998) 'educational reconstruction' framework. We acknowledge that the decision to adopt a qualitative methodology and the composition of our sample, which consisted of university staff and post-graduate students primarily, has implications for the generalizability of the findings presented below. Further research incorporating a broader array of actors could therefore elicit divergent views and shed additional light on the topic at hand.

The key finding from our study is that against a backdrop of financial constraints, political transformation and uncertainty, the reform process has resulted in the physical renovation of Yangon University's basic infrastructure and the provision of learning materials. Problematically, stakeholders deem these changes as decorative, inadequate and somewhat superficial. Much to the frustration of academic staff and students, there has been a remarkable failure to initiate the ideological reconstruction deemed necessary to alter previous authoritarian practices, and create an environment in which critically informed pedagogical activities can flourish. Furthermore, the current reform process has overlooked the psychological reconstruction of the university, resulting in a climate of low morale, fear and anxiety amongst staff.

When we began writing this article we knew that the timing of the 2015 national elections would prevent our findings being of use during the previous government's remaining time in power. Nevertheless, the issue of higher education reform is unlikely to disappear from the political agenda. Therefore this paper will serve as a much needed reference point for policy makers in Aung San Suu Kyi's 'National 
League for Democracy' attempting to reform Myanmar's higher education system in the future. Additionally, although focusing on one institution, the findings contributed to wider debates over higher education reforms by states in the Global South undergoing political transformations.

Existing literature rightly highlights that university reform, like other processes leading to significant institutional change, involves a relinquishment of the status quo in the hope of obtaining something better in the future. In the context of educational reforms in States undergoing political transformation from authoritarian rule to democratic modes of governance, we illustrated why it is important for stakeholders not to focus on the institutional level primarily. In an age where there is considerable competition between institutions at the national and international level to achieve 'world class' status, this line of thinking goes against prevailing policy rhetoric. However, the shortcoming in this institutional focused approach is that it fails to recognize that the adoption of democratic procedures by a university is directly linked to, and influenced by, the political transformation taking place in the society within which the university operates. Accordingly, as evidenced by the case study of Yangon University, states in the Global South undergoing political transformation should strive to reform the education system as a whole. 


\section{Acknowledgments:}

First and foremost, we would like to thank all the participants who bravely agreed to take part in this study. We are also grateful to Brasenose College, University of Oxford, for financial assistance to cover travel and fieldwork costs. Lastly, we would like to thank Hubert Ertl and the anonymous referees for their comments and suggestions. 


\section{References}

Altbach, Philip G. "Academic freedom in a global context: 21st century challenges." The NEA 2007 Almanac of Higher Education (2007): 49-56.

Amonoo-Neizer, Eugene H. "Universities in Africa-the need for adaptation, transformation, reformation and revitalization." Higher Education Policy 11, no. 4 (1998): 301-309.

Amsterdamski, Stefan, and Aaron Rhodes. "Perceptions of dilemmas of reform: remarks and interpretations concerning a study by the Vienna Institute for Human Sciences." European Journal of Education (1993): 379-402.

Anderson, Don, and Richard Johnson. University autonomy in twenty countries. Canberra: Department of Employment, Education, Training and Youth Affairs, 1998.

Arnhold, Nina, Julia Bekker, Natasha Kersh, Elizabeth A. Mcleish, and David Phillips. "Education for reconstruction: the regeneration of educational capacity following national upheaval." Symposium Books Ltd, (1998).

Asian Development Bank. (2012). "Interim Country Partnership Strategy: Myanmar (20122014)" Retrieved from http://www.adb.org/documents/myanmar-interim-country-partnershipstrategy-2012-2014

Aung-Thwin, Michael, and Maitrii Aung-Thwin. A history of Myanmar since ancient times: Traditions and transformations. London: Reaktion Books, (2013).

Batsukh, Tungalag. (2011). Mongolian Higher Education Reform During the Transition to a Democratic Market-Based Society 1990-2010" PhD Diss., University of Pittsburgh (2011). Retrieved from http://d-scholarship.pitt.edu/10852/1/ETD Batsukh 822 11.pdf 
Bennich-Björkman, Li. "Why universities need leaders: The importance of departmental leadership" in Brennan." J., Fedrowitz, J., Huber, M. and Shah, T.(Eds)(1999) What Kind of University (1999): 118-127.

Cerych, Ladislav. "Educational reforms in central and eastern Europe." European Journal of Education (1995): 423-435.

Cohen, Louis, Lawrence Manion, and Keith Morrison. Research methods in education. Routledge, (2013).

Deaver, Michael V. "Democratizing Russian higher education." Demokratizatsiya 9, no. 3 (2001): 350.

Dill, David D. "Capacity building as an instrument of institutional reform: Improving the quality of higher education through academic audits in the UK, New Zealand, Sweden, and Hong Kong." Journal of Comparative Policy Analysis: Research and Practice 2, no. 2 (2000): 211-234.

Esson, James, and Hubert Ertl. "Securing the Future of Higher Education in England." The Political Quarterly 84, no. 3 (2013): 404-409.

Farrant, John H., and Lioudmila M. Afonso. "Strategic planning in African universities: how relevant are Northern models?" Higher Education Policy 10, no. 1 (1997): 23-30.

Hendrichová, J. "Recent developments in higher education in Central and Eastern Europe: Selected issues". In K. Hüfner (Ed.), (1995). Higher Education Reform Processes in Central and Eastern Europe (pp. 63-78). Frankfurt: Peter Lang. 
Hall, M. and Symes, A., South African higher education in the first decade of democracy: from cooperative governance to conditional autonomy. Studies in Higher Education, 30, no. 2 (2005): 199-212.

Holliday, Ian. "Ethnicity and democratization in Myanmar." Asian Journal of Political Science 18, no. 2 (2010): 111-128.

Holsti, Kalevi Jaakko. Why nations realign: Foreign policy restructuring in the postwar world. London: Routledge, (2015).

Institute of International Education." Investing in the Future: Rebuilding Higher Education in Myanmar" (2013) New York: Institute of International Education. Retrieved from http://www.iie.org/Research-and-Publications/Publications-and-Reports/IIEBookstore/Rebuilding-Higher-Education-in-Myanmar

Johnstone, Donald Bruce, Alka Arora, and William Experton. The financing and management of higher education: A status report on worldwide reforms. Washington, DC: World Bank, (1998).

Karran, Terence. "Academic freedom: in justification of a universal ideal." Studies in Higher Education 34, no. 3 (2009): 263-283.

King, Kenneth. "Higher education and international cooperation: The role of academic collaboration in the developing world." Higher education and international capacity building: Twenty-five years of higher education links (2009): 33-49.

Kyi, Khin Maung, R. Finley, R. M. Sundrum, Mya Maung, Myo Nyunt, and Zaw Oo. "Economic Development of Burma. A Vision and a Strategy" Stockholm: Olof Palme International Centre. (2000). 
Lall, Marie. "Evolving education in Myanmar: The interplay of state, business and the community." Dictatorship, disorder and decline in Myanmar (2008): 127-150. Retrieved from http://www.oapen.org/download?type=document\&docid=458944\#page $=137$

Luhanga, Matthew. "Strategic planning of higher education institutions in Africa: A case study of the University of Dar-es-Salaam." Procedia-Social and Behavioral Sciences 2, no. 5 (2010): 70717085.

Mann, Zarni. 2014. “Government Neglecting Student Demands, Mandalay Protestors Say." Retrieved from http://www.irrawaddy.org/burma/govt-neglecting-student-demandsmandalay-protestors-say.html.

Marga, Andrei. "Reforming the postcommunist university." Journal of Democracy 8, no. 2 (1997): 159-167.

McKenzie, Kevin. "Policy Insights for Higher Education: Recommendations for HE reform in Myanmar". The British Council. (2013). Retrieved from

https://www.britishcouncil.org/education/ihe/knowledge-centre/national-policies/policyinsights-he-recommendations-myanmar

Musisi, Nakanyike B., and Nansozi K. Muwanga. "Makerere University in transition 1993-2000: Opportunities and challenges." Oxford and Kampala: James Currey and Fountain Publishers. (2003).

Myanmar Ministry of Education. "Terms of Reference for Myanmar Comprehensive Education Sector Review". Yangon: Myanmar Ministry of Education. (2012). 
Obama, Barack. "Remarks by President Obama at the University of Yangon." The White House, Office of the Press Secretary. (2012). Retrieved from https://www.whitehouse.gov/the-pressoffice/2012/11/19/remarks-president-obama-university-yangon

Robson, Colin. "Real World Research: A resource for social scientists and resources." Oxford: Blackwell Publishing (2002).

Sadlak, Jan. "Higher education reform in Romania: Challenges and responses." Higher Education Reform Process in Central and Eastern Europe. Frankfurt: Peter Lang (1995).

Teferra, Damtew, and Philip G. Altbachl. "African higher education: Challenges for the 21st century." Higher education 47, no. 1 (2004): 21-50.

Weng, L. "Key Education Reforms Will Start at Rangoon University, Suu Kyi Says". (2012). Retrieved from http://www.irrawaddy.org/archives/22495 